Patricia S. Pollard is an economist and Research Officer at the Federal Reserve Bank of St. Louis. Cletus C. Coughlin is a vice president and the Associate Director of Research at the Federal Reserve Bank of St. Louis. Heidi Beyer provided research assistance.

\section{Going Down: The Asian Crisis and U.S. Exports}

\author{
Patricia S. Pollard and \\ Cletus C. Coughlin
}

r he Asian economic and financial crisis has attracted attention to the trade links among the United States and countries throughout Asia. ${ }^{1}$ The trade channel is undoubtedly an important mechanism through which this crisis affects the U.S. economy. As the effects on Asian economies became more pronounced and the effects of the crisis spread to other countries in spring and summer 1998, changes in U.S. trade became more visible and concerns about the possibility of a U.S. recession increased. ${ }^{2}$ N onethel ess, the U.S. economy remained robust in 1998 . Declining commodity prices (partly a result of reduced demand in Asia) and declining interest rates (partly a result of flight-to-quality capital inflows and the Federal Reserve's easing of monetary policy in reaction to the Asian crisis) helped spur consumption and investment spending. This spending tended to offset the weakening of export spending, especially spending on goods destined for Asia.

Our primary goal in this paper is to provide some rough estimates of the sizes of the export shock to the U.S. economy, generally, and the shock to specific sectors associated with the Asian crisis. We begin by providing some background material, such as facts about both the magnitude and changes of U.S. exports over time. N ext, we examine the flow of exports to Asia and other regions. The Asian crisis has reduced recent growth, as well as near-term growth prospects throughout Asia, and has caused large declines in the U.S. dollar exchange value of many Asian currencies. These changes have caused a reduction in U.S. exports to Asia. We estimate the reduction in U.S. exports- first on an overall basis and second on an industry basis. In the process we attempt to identify any recent worsening of export performance and any damage being suffered by specific industries.

\section{HOW IMPORTANT \\ ARE EXPORTS FOR}

THE U.S. ECONOMY?

During 1997, U.S. exports totaled $\$ 965.4$

billion; 71 percent were exports of goods, and 29 percent were exports of services. Exports are a relatively small, al beit increasing, share of U.S. economic activity. A straightforward calculation of the current dollar value of exports in 1997 divided by gross domestic product (GDP) reveals an export share of 11.9 percent, as shown in Figure 1. In 1960 this share was 4.8 percent. Another calculation, which adjusts both exports and GDP for their respective price changes, yields a slightly different result. Real exports of goods and services accounted for 16.7 percent of real GDP in 1997, 11.9 percentage points higher than its level in 1960. ${ }^{3}$ Thus, the increase in the importance of the export sector is larger when the dollar values of exports and output are adjusted for relative price changes. This is because the prices of all goods and services included in GDP have increased by more than the prices of goods and services that are exported. Figure 1 also indicates the sharp increase in the importance of the export sector to the overall economy since the mid-1980s. Adjusted for relative price changes, the share of U.S. output that is exported has doubled during the past 15 years.

The growth of the export sector has been a driving force in the current expansion, as shown in Figure 2. For example, growth in exports of goods and services accounted for 1.6 percentage points of the
${ }^{1}$ The economic and financial crisis in Asia has spawned voluminous popular and academic literature. An excellent source that identifies much of this literature is a web page produced by Nouriel Roubini that can be found at the following Internet address: <http:/ / www.stern. nyu.edu/ nroubini/ asia/ AsiaH omepage. html>. For an elementary introduction to the Asian crisis, see Neely (1999).

2 For example, Alan Greenspan in his September 1998 testimony before the U.S. Senate Committee on the Budget (1998, p. 1) said: " ... it is just not credible that the United States, or for that matter Europe, can remain an oasis of prosperity unaffected by a world that is experiencing greatly increased stress."

${ }^{3}$ Since both price indexes use $1960=100$, the nominal and relative price adjusted shares for 1960 are equal. 


\section{Figure 1}

\section{Exports of Goods and Services \\ Percent of GDP, 1960-98}

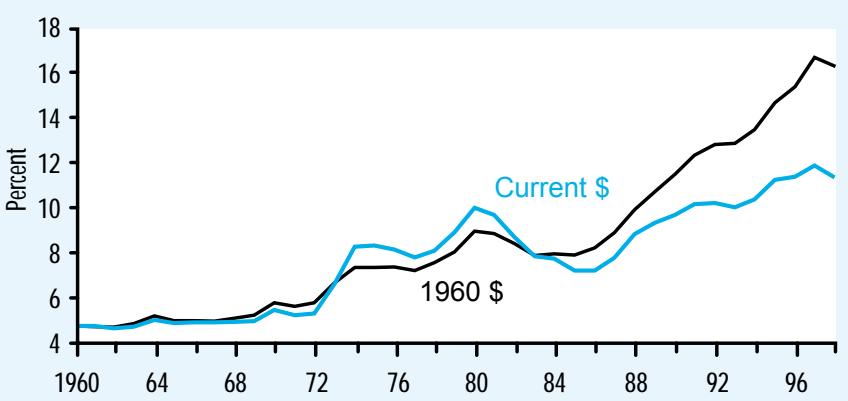

Source: U.S. Department of Commerce, Bureau of Economic Analysis.

\section{Figure 2}

Export Contribution to Growth 1992-1998

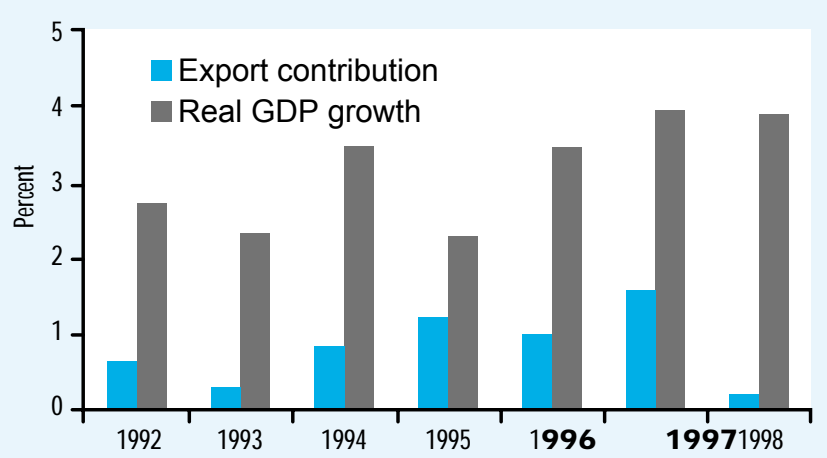

Source: U.S. Department of Commerce, Bureau of Economic Analysis.

3.9 percentage point growth in real GDP during 1997. During 1992-97, growth in exports accounted for more than 30 percent of the growth in real GDP.

After growing by 8.5 percent in 1996 and 12.8 percent in 1997, real exports of U.S. goods and services rose by only 1.6 percent in 1998. Moreover, exports declined during each of the first three quarters of 1998 (on an annualized basis) before rising sharply in the fourth quarter. Thus, in contrast to the 1992-97 period, exports accounted for only 0.2 percentage points of the 3.9 percentage point growth in real GDP in 1998.

Because data on U.S. exports of services are not available by country of destination for all East Asian countries, the remainder of this article focuses on exports of goods. Similar to the results associated with exports of goods and services, exports of goods have been especially important for the current expansion, at least until 1998. Between 1992 and 1997, exports of goods in nominal terms grew at an annual rate of 9.0 percent, increasing the ratio of exports of goods to GDP from 7.2 percent to 8.5 percent. The growth of exports is even more impressive when expressed in real terms. Between 1992 and 1997, real exports of goods increased at an annual rate of 13.1 percent. Adjusted for their respective relative price changes, the ratio of exports of goods to GDP increased from 7.2 percent to 11.5 percent.

\section{GEOGRAPHICAL PATTERN OF U.S. EXPORTS \\ Coinciding with the increase in U.S.} exports has been a shift in its geographical pattern, as shown in Figure 3 and Table 1. Figure 3 shows the destination of U.S. exports of goods by geographical area during the periods 1970-75 and 1992-97. Table 1 lists the 10 countries that received the most U.S. exports during these periods. The Western Hemisphere has been the most important region for U.S. exports during both periods, and its importance has grown slightly. As shown in Table 1, this is a result of an increase in the share of exports going to Mexico, some of which can be attributed to the effects of the N orth American Free Trade Agreement (NAFTA). In contrast, Africa and the Middle East have never been important export markets for the United States. These two areas combined receive only 5 percent of U.S. exports.

The most notable change in the pattern of U.S. exports during the past three decades has been the increasing importance of the Asia-Pacific area and the declining importance of Europe. Over the period 1970-75, 32 percent of U.S. exports were shipped to European countries, whereas 22 percent of U.S. exports were shipped to Asia-Pacific countries. Over the period 1992-97, Europe received 25 percent of U.S. exports and the 
Asia-Pacific region received 31 percent. During the earlier period, six of the 10 most important export markets for the United States were in Europe, whereas currently only four of the top 10 markets are in Europe. ${ }^{4}$ In contrast, over the period 1970-75, Japan was the only Asia-Pacific country in the top 10 list, whereas currently four countries in the region are on the list. M oreover, the emergence of the Asia-Pacific region as the second-most important geographic area for U.S. exports is not due to growth in exports to Japan relative to all other areas; rather, it has resulted from the growing importance of the markets in the rest of East Asia, as shown in Figure $4 .^{5}$ In fact, the share of U.S. goods exports shipped to Japan has fallen sharply during the 1990s relative to the late 1980s. M eanwhile, with the exception of Taiwan, the share of U.S. goods shipped to other countries throughout East Asia rose sharply during the 1990s relative to the late 1980s.

Undoubtedly, the key factor underlying the increasing relative importance of markets in East Asia for U.S. production has been the rapid income growth in most East Asian countries. Table 2 shows that, excluding Japan, countries in East Asia generally grew much faster during 1992-97 than other economies-especially the major European trading partners of the United States. In addition, the relatively slow economic growth in Japan is consistent with the fact that the increasing importance of the Asia-Pacific region for U.S. exports is not due to Japan.

\section{EXPORTS TO ASIA AND U.S. ECONOMIC GROWTH}

It is precisely the increased importance of the East Asian markets for U.S. exporters that has made the U.S. economy more vulnerable to the substantial income and exchange rate changes associated with the Asian crisis. Table 3 contains information on the sharp decline in growth and, in many cases, absolute declines in overall economic activity throughout East Asia between 1997 and 1998. In seven of the 10 countries listed, total activity shrank during 1998. For Indonesia, Thailand, Korea, Malaysia

\section{Figure 3}

Global Distribution
of U.S. Goods Export

1970-1975

1992-1997
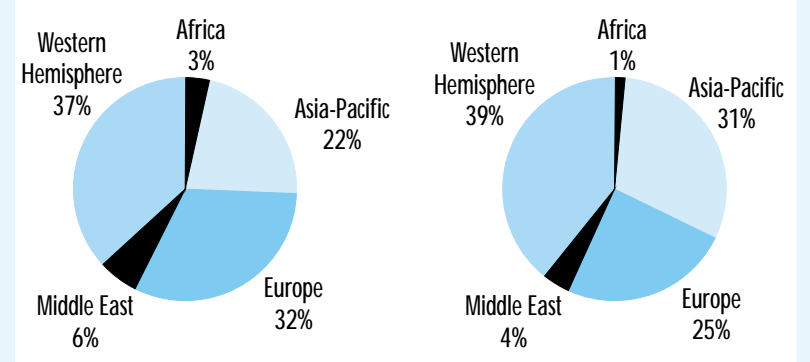

Source: U.S. Department of Commerce, Bureau of the Census

\section{Table 1}

Top Ten Destinations of U.S. Goods Exports

(By Share of Total U.S. Exports)

\begin{tabular}{|c|c|c|c|}
\hline \multicolumn{2}{|c|}{$1970-75$} & \multicolumn{2}{|c|}{1992.97} \\
\hline Country & $\begin{array}{c}\text { Share } \\
\text { (Percent) }\end{array}$ & Country & $\begin{array}{c}\text { Share } \\
\text { (Percent) }\end{array}$ \\
\hline Canada & 21.4 & Canada & 21.5 \\
\hline Japan & 10.2 & Japan & 10.4 \\
\hline Germany & 5.4 & Mexico & 9.3 \\
\hline United Kingdom & 4.9 & United Kingdom & 5.2 \\
\hline Mexico & 4.4 & Germany & 3.9 \\
\hline Netherlands & 3.9 & Korea & 3.8 \\
\hline France & 3.1 & Taiwan & 3.2 \\
\hline Italy & 2.9 & Netherlands & 2.8 \\
\hline Brazil & 2.7 & France & 2.6 \\
\hline $\begin{array}{l}\text { Belgium- } \\
\text { Luxembourg }\end{array}$ & 2.3 & Singapore & 2.5 \\
\hline
\end{tabular}

Sources: U.S. Department of Commerce, Bureau of the Census and International Monetary Fund, Direction of Trade Statistics.

and Hong Kong, the declines were particularly large. Only China and Taiwan had strong economic growth in 1998. In both countries, however, economic growth slowed in 1998 relative to 1997.

In addition to the sharp declines in growth, many countries in East Asia have experienced sharp declines in their currencies relative to the U.S. dollar. Table 4 shows

\footnotetext{
${ }^{4}$ Belgium and Luxembourg are counted as a single country in the trade data.

${ }^{5}$ In this article, East Asia is defined as China, Hong Kong, Indonesia, Japan, Korea, Malaysia, Philippines, Singapore, Taiwan and Thailand.
} 
${ }^{6}$ To be precise, real exchange rate changes, which adjust the nominal exchange rates for the relative rates of inflation, should be used. The use of real exchange rates would not alter the conclusion that many countries in East Asia have experienced sharp dedines in their currencies relative to the U.S. dollar.

${ }^{7}$ Clearly, these estimates are rough. An important assumption is that the resources that would have been used to produce the exports are not put to other uses immediately. Also, to the extent that the decline in demand for U.S. products by the East Asian countries has resulted in a rise in inventories, the negative effects on measured output are reduced. That is, the decline in exports may be offset by a rise in inventories in the GDP accounts. Unless producers find other markets for these inventories, however, production ultimately will be affected.

8 Year-over-year (rather than quarterly annualized) comparisons are used because the country-level export data are not seasonally adjusted. Thus, fluctuations in quarterly data could reflect seasonal patterns rather than economic factors.

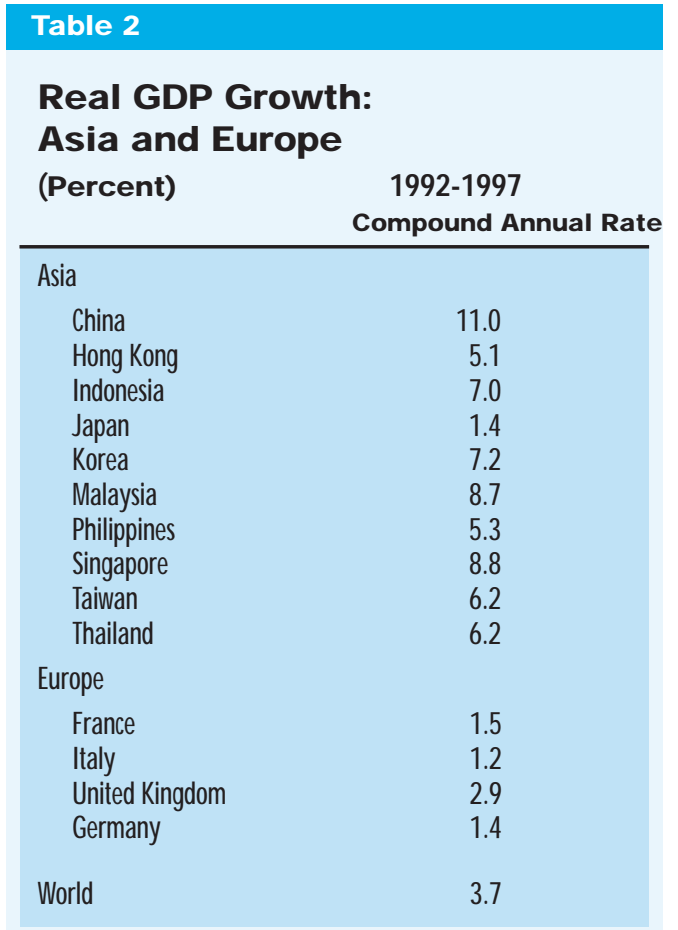

Source: International Monetary Fund, International Financial Statistics.

\section{Table $\mathbf{3}$}

\section{Asian Real GDP Growth} (Percent)

\begin{tabular}{lcc} 
& $\mathbf{1 9 9 7}$ & $\mathbf{1 9 9 8}$ \\
\hline China & 8.8 & 7.8 \\
Hong Kong & 5.3 & -5.1 \\
Indonesia & 4.6 & -13.7 \\
Japan & 1.4 & -2.8 \\
Korea & 5.5 & -5.5 \\
Malaysia & 7.7 & -6.8 \\
Philippines & 5.2 & -0.5 \\
Singapore & 8.0 & 1.5 \\
Taiwan & 6.8 & 4.9 \\
Thailand & -0.4 & -8.0
\end{tabular}

Source: International Monetary Fund, World Economic Outlook (May 1999).

the measured changes for two periodsMay 1, 1997 to January 30, 1998 and May 1, 1997 to December 31, 1998. Between May 1, 1997 and January 30, 1998, seven of the 10 East Asian countries experienced declines of more than 15 percent in the value of their currencies relative to the U.S. dollar. The declines in the Indonesian rupiah and the Thai baht were especially sharp-both currencies fell more than 50 percent against the U.S. dollar. When the longer period is examined, one sees that the Asian currencies have recovered somewhat. The fact remains, however, that between May 1, 1997 and December 31, 1998 , seven of the 10 countries listed saw their currencies decline more than 10 percent against the U.S. dollar. ${ }^{6}$

Undoubtedly, these income and exchange rate changes adversely affected U.S. exports to Asia. One rough estimate of the export effect of the Asian crisis on the U.S. economy can be obtained by calculating the effect of the decline in U.S. exports to Asia on the growth rate of output. ${ }^{7}$ Real merchandise exports to East Asia fell by 11.6 percent in 1998. This decline reduced the growth rate of real GDP by 0.36 percentage points. Consequently, the growth rate of real GDP in 1998 was 3.85 percent rather than 4.21 percent. The quarterly data show that exports to East Asia fell by 7.4 percent on a yearover-year basis in the first quarter of 1998, by 16 percent in both second and third quarters, and by 7.1 percent in the fourth quarter. ${ }^{8}$ These declines had the effect of lowering the growth rate of real GDP by 0.2 percentage points during the first and fourth quarters and 0.5 percentage points in the second and third quarters. These data provide some evidence that the worst effects of the Asian crisis may be over.

\section{Industry Effects}

The recent declines in exports to East Asia have not equally affected the output of all industries. The effect of declining exports to Asia on a particular U.S. industry depends on the following two factors: the extent to which exports to Asia have declined and the importance of these exports to the output of a particular industry. To examine these effects, we grouped industries according to the two-digit Standard Industrial Classification (SIC) system. Details regarding the data are provided in the shaded insert 
"Details of Industry Level Export and Output Data."

Declining Exports. First, we look at the change in exports by industry. As Table 5 indicates, in real terms every industry studied, with the exception of the transportation equipment industry (SIC 37), saw a decline in goods exported to East Asia in 1998. Exports of transportation equipment rose by 3.5 percent during 1998. These exports rose in all but the second quarter of 1998 . Of those industries with declining exports, the food and kindred products industry (SIC 20) experienced the smallest decline (3.3 percent) during 1998. Metallic ores and concentrates industry (SIC 10) exports fell by the greatest amount ( 34.9 percent). More than half of all the U.S. industries studied saw their exports to East Asia fall 20 percent or more during 1998.

Though the change in exports of some industries showed a great deal of quarterly variation (even on a year-over-year basis), exports in other industries fell sharply during each quarter. For example, crude oil and natural gas (SIC 13) exports declined by more than 30 percent during the first, third and fourth quarters but rose by 28 percent during the second quarter. In contrast, five industries-forestry and fishing (SIC 08-09), stone, clay, glass and concrete products (SIC 32), apparel and related products (SIC 23), rubber and miscellaneous plastic products (SIC 30), and furniture and fixtures (SIC 25)-experienced year-over-year declines in exports of 15 percent or more during each quarter.

In most of the industries studied, the five Asian countries most directly associated with the crisis-Indonesia, Malaysia, Philippines, South Korea and Thailand-experienced the largest declines in exports. China has been the one bright spot in East Asia for many industries. More than half of the industries studied had increased exports to China.

Examining the export data at a more disaggregated level can provide more information on what is driving the changes in exports at the two-digit industry level. ${ }^{9}$ For example, the 3.5 percent increase in transportation equipment (SIC 37) exports occurred as a result of rising aircraft

\begin{tabular}{|c|c|c|}
\hline \multicolumn{3}{|c|}{$\begin{array}{l}\text { Exchange Rate Change } \\
\text { US \$/Foreign Currency } \\
\text { (Percent) }\end{array}$} \\
\hline & $\begin{array}{c}\text { May 1, } 1997 \text { - } \\
\text { January } 30,1998\end{array}$ & $\begin{array}{c}\text { May 1, } 1997 \text { - } \\
\text { December 31, } 1998\end{array}$ \\
\hline China & 0.2 & 0.6 \\
\hline Hong Kong & 0.1 & 0.0 \\
\hline Indonesia & -76.6 & -68.8 \\
\hline Japan & -0.4 & 12.0 \\
\hline Korea & -41.4 & -25.8 \\
\hline Malaysia & -40.7 & -34.0 \\
\hline Philippines & -38.1 & -31.9 \\
\hline Singapore & -15.7 & -12.4 \\
\hline Taiwan & -19.2 & -14.2 \\
\hline Thailand & -50.8 & -28.5 \\
\hline
\end{tabular}

exports, primarily to China. In contrast, passenger car exports fell throughout 1998.

Another industry experiencing a relatively small decline in exports to East Asia is tobacco products (SIC 21). Overall, tobacco exports to East Asia fell by 4.9 percent in 1998. A slight rise in the export of chewing and smoking tobacco was more than offset by a decline in cigarette exports.

Turning to industries that have experienced sharp declines, the decline in exports of finfish are primarily responsible for the decline in forestry and fishing (SIC 08-09) exports. Meanwhile, declines in corn, soybeans and cotton exports accounted for nearly all of the decline in agriculture and livestock products (SIC 01-02) exports.

These export data suggest both the widespread and differential effects of the Asian crisis on U.S. exporters. Obviously, certain industries have experienced much larger drops in exports than other industries. Understanding the full extent of the export effect across industries, however, requires examining the importance of exports to East Asia for the industries studied.

Industry Dependence on Exports. The electrical and electronic machinery, equipment and supplies industry (SIC 36) is the only industry whose exports to East Asia accounted for more than 10 percent
${ }^{9}$ These data are available
on request. 


\section{Figure 4}

U.S. Goods Exports to East Asia

Share of total exports, 1970-1997 (Percent)
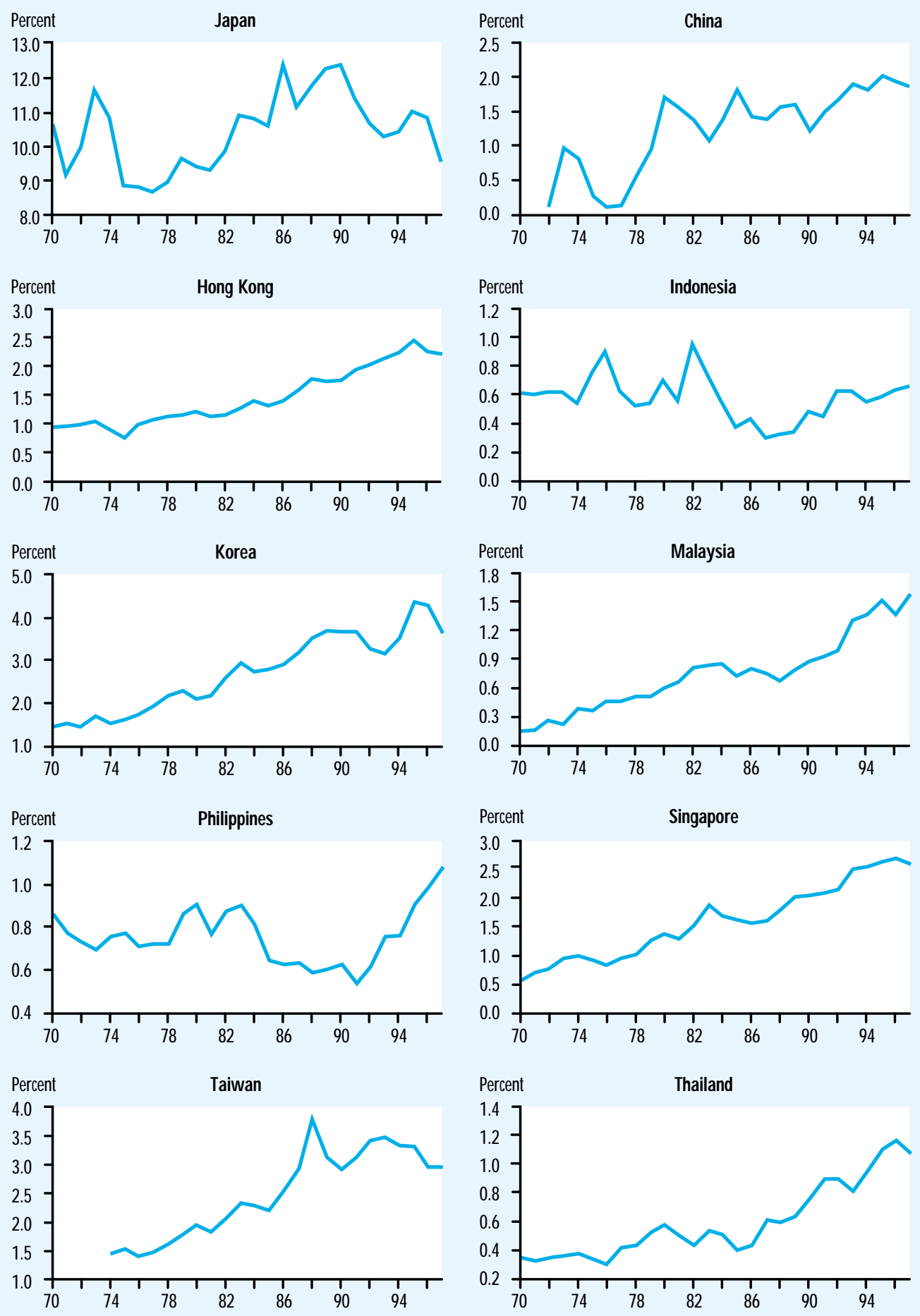

Sources: U.S. Department of Commerce, Bureau of the Census and International Monetary Fund, Direction of Trade Statistics. 


\section{Table 5}

\section{U.S. Real Exports to East Asia by Industry \\ (Percent Change From Year Ago)}

\begin{tabular}{|c|c|c|c|c|c|c|}
\hline \multirow[b]{2}{*}{ SIC } & \multirow[b]{2}{*}{ Industry } & \multicolumn{5}{|c|}{1998} \\
\hline & & Year & Q1 & Q2 & Q3 & Q4 \\
\hline 10 & Metallic ores and concentrates & -34.9 & -55.6 & -40.1 & 5.8 & -66.4 \\
\hline 13 & Crude oil and natural gas & -32.3 & -33.2 & 27.5 & -47.2 & -55.6 \\
\hline 24 & Lumber and wood products, except furniture & -32.0 & -38.9 & -41.6 & -29.6 & -10.8 \\
\hline $08-09$ & Forestry and fishing & -29.1 & -26.8 & -43.8 & -25.9 & -20.5 \\
\hline 32 & Stone, day, glass and concrete products & -28.8 & -20.4 & -24.7 & -27.7 & -41.1 \\
\hline 29 & Refined petroleum and coal products & -27.6 & -42.3 & -42.0 & -29.3 & 23.8 \\
\hline 22 & Textile mill products & -24.9 & -9.0 & -27.1 & -34.6 & -28.3 \\
\hline 33 & Primary metal products & -23.1 & -13.8 & -28.8 & -27.7 & -21.4 \\
\hline 23 & Apparel and related products & -22.6 & -24.5 & -23.1 & -24.6 & -17.4 \\
\hline 39 & Miscellaneous manufactured goods & -22.4 & -23.9 & -26.6 & -26.5 & -11.4 \\
\hline 35 & Nonelectrical machinery & -21.6 & -12.5 & -21.3 & -25.9 & -26.1 \\
\hline 30 & Rubber and miscellaneous plastics products & -21.4 & -15.5 & -23.8 & -27.9 & -18.3 \\
\hline 25 & Furniture and fixtures & -21.3 & -21.3 & -28.7 & -17.6 & -16.3 \\
\hline 26 & Paper and allied products & -21.3 & -23.7 & -23.4 & -27.0 & -10.2 \\
\hline 28 & Chemicals and allied products & -17.1 & -19.8 & -18.5 & -20.7 & -9.1 \\
\hline 12 & Bituminous coal and lignite & -14.5 & -2.2 & -15.8 & -20.0 & -21.2 \\
\hline $01-02$ & Agriculture and livestock products & -13.5 & -14.9 & -18.5 & -12.2 & -8.9 \\
\hline 31 & Leather and leather products & -12.4 & -23.3 & -2.4 & -12.3 & -11.6 \\
\hline 34 & $\begin{array}{l}\text { Fabricated metal products except machinery } \\
\text { and transportation equipment }\end{array}$ & -12.4 & -9.5 & -22.0 & -24.0 & 6.4 \\
\hline 38 & $\begin{array}{l}\text { Scientific and professional instruments; } \\
\text { photographic and optical goods, etc. }\end{array}$ & -10.2 & -3.1 & -8.2 & -12.5 & -16.4 \\
\hline 36 & $\begin{array}{l}\text { Electrical and electronic machinery, } \\
\text { equipment and supplies }\end{array}$ & -7.3 & -3.1 & -12.5 & -10.1 & -3.5 \\
\hline 14 & Nonmetallic minerals, except fuels & -7.3 & -7.0 & 4.9 & -15.9 & -10.6 \\
\hline 21 & Tobacco products & -4.9 & -5.4 & 0.2 & -5.7 & -8.5 \\
\hline 27 & Printing and publishing & -3.6 & -9.6 & 8.8 & -12.8 & -1.3 \\
\hline 20 & Food and kindred products & -3.3 & -3.0 & -0.7 & -7.7 & -1.9 \\
\hline 37 & Transportation equipment & 3.5 & 11.9 & -18.8 & 1.3 & 22.5 \\
\hline
\end{tabular}

Sources: U.S. Department of Commerce, Bureau of the Census and U.S. Department of Labor, Bureau of Labor Statistics.

of gross output during 1996, as shown in Table $6 .{ }^{10}$ For the U.S. industries studied, 1996 exports to East Asia accounted for, on average, 3.7 percent of gross output. Though these numbers may seem small, they are not surprising. Exports of goods accounted for only 8.2 percent of U.S. GDP during 1996, with exports to Asia accounting for about one-third of the total.
Exports to East Asia accounted for 2.5 percent of the gross output of the paper and allied products industry (SIC 26) during 1996, but only 0.7 percent of the gross output of the furniture and fixtures industry (SIC 25). Exports to East Asia for both industries fell by 21.3 percent during 1998. As a result of the differences in the importance of East Asian markets, this
${ }^{10}$ The most recent output-byindustry data are for 1996. 


\section{Table 6}

\section{U.S. Real Exports to East Asia as a Percent of Gross Output by Industry (1996)}

\begin{tabular}{|c|c|c|}
\hline SIC & Industry & Percent \\
\hline 36 & $\begin{array}{l}\text { Electrical and electronic machinery, } \\
\text { equipment and supplies }\end{array}$ & 12.2 \\
\hline 31 & Leather and leather products & 8.5 \\
\hline 35 & Nonelectrical machinery & 8.2 \\
\hline 38 & $\begin{array}{l}\text { Scientific and professional instruments; } \\
\text { photographic and optical goods, etc. }\end{array}$ & 7.5 \\
\hline 01-02 & Agriculture and livestock products & 6.9 \\
\hline 39 & Miscellaneous manufactured goods & 5.8 \\
\hline 21 & Tobacco products & 5.1 \\
\hline 28 & Chemicals and allied products & 4.5 \\
\hline 08-09 & Forestry and fishing & 4.4 \\
\hline 37 & Transportation equipment & 4.1 \\
\hline 24 & Lumber and wood products, except furniture & 3.8 \\
\hline 14 & Nonmetallic minerals, except fuels & 2.6 \\
\hline 26 & Paper and allied products & 2.5 \\
\hline 33 & Primary metal products & 2.5 \\
\hline 12 & Bituminous coal and lignite & 2.5 \\
\hline 10 & Metallic ores and concentrates & 2.5 \\
\hline 20 & Food and kindred products & 2.2 \\
\hline 34 & $\begin{array}{l}\text { Fabricated metal products except machinery } \\
\text { and transportation equipment }\end{array}$ & 1.8 \\
\hline 23 & Apparel and related products & 1.7 \\
\hline 32 & Stone, clay, glass and concrete products & 1.6 \\
\hline 30 & Rubber and miscellaneous plastics products & 1.4 \\
\hline 22 & Textile mill products & 1.1 \\
\hline 29 & Refined petroleum and coal products & 1.0 \\
\hline 25 & Furniture and fixtures & 0.7 \\
\hline 13 & Crude oil and natural gas & 0.4 \\
\hline 27 & Printing and publishing & 0.3 \\
\hline
\end{tabular}

Sources: U.S. Department of Commerce, Bureau of the Census and U.S. Department of Labor, Bureau of Labor Statistics.

${ }^{11}$ See the shaded insert,

"Another Look at Industry Output Effects," for a discussion of our crossindustry results relative to a study by Noland et al. (1998) using a different approach. equal percentage decline in exports will have a much larger effect on the former industry than on the latter.

Gross Output Effects. Given the sharp decline in exports to East Asia during 1998, the effect on the gross output of several industries has been pronounced, as shown in Table 7.11 These data indicate the potential effect of the decline in exports on the growth rate of each industry, assuming this reduction in export sales to Asia is not offset by additional sales in the U nited States or elsewhere. The average effect across industries was a 0.6 percent decline in the growth rate of gross output. The industries most severely affected by the decline in exports are nonelectrical machinery (SIC 35) and miscellaneous manufactured goods (SIC 39). The former industry includes such items as construction, metal working and general industrial machinery as well as computers. The latter industry includes such items as jewelry, toys, musical instruments, and office and art supplies.

In the absence of a decline in nonelectrical machinery exports to East Asia, the growth rate of gross output in that industry would have been 1.8 percentage points higher. Similarly, the decline in miscellaneous manufactured goods exports to East Asia reduced gross output growth in that industry by 1.3 percentage points. The factors accounting for these output effects differ in the two industries. The nonelectrical machinery industry is more dependent on East Asia for sales of its output (8.2 percent compared with 5.8 percent), whereas the miscellaneous manufactured goods industry suffered a slightly greater decline in exports to the region (22.4 percent compared with 21.6 percent).

The transportation equipment industry (SIC 37) received a small boost in output ( 0.14 percentage points) as a result of rising exports to East Asia. Of the studied industries with a decline in exports, output of the printing and publishing industry (SIC 27) has been the least affected. Declining exports lowered the growth rate by only 0.01 percentage points during 1998. The limited effect is a result of both the small amount of production that is exported to East Asia ( 0.3 percent) and the small decline in these exports ( 3.6 percent). Even the 13 percent drop in exports of this industry that occurred during the third quarter had only a 0.04 percentage point drag on growth.

The crude oil and natural gas industry (SIC 13), which had one of the largest declines in exports during 1998 (32.3 percent), was in the bottom fifth of industries in terms of the effect of the decline in exports 


\section{DETAILS OF INDUSTRY LEVEL EXPORT AND OUTPUT DATA}

\section{Export Data}

Export data by industry for the group of countries studied are available only for merchandise trade and only in current dollars. Exports by industry are based on the two-digit Standard Industrial Classification (SIC) system. This classification of exports was chosen for consistency with the output data, discussed below.

To calculate the real value of exports by industry, the data were deflated by export price indices. Export price index data are not available on a SIC basis. Thus, we started with an export price index that groups the data based on the Standard International Trade Classification (SITC) system and matched these industries with the appropriate SIC codes. When multiple SITC codes fit one SIC category, a weighted average of the price indices for those categories was constructed to arrive at the price index on an SIC basis. The weights were based on the export share of each SITC industry within a SIC grouping for 1995 because this is the year used to weight prices in the SITC index. For example, the table in this insert provides information on the two SITC industries (SITCs 78 and 79) that correspond to the transportation equipment industry (SIC 37). Using this information, the relevant price index for the transportation equipment industry was 101.24 during the first quarter of 1997 and 101.02 during the first quarter of 1998. Thus, the export price of transportation equipment fell by 0.2 percent during this period.

\section{O utput Data}

Output data by industry are based on the two-digit SIC code system. The output data are gross output by industry for 1996 (the latest year for which such data are available). Gross output measures each industry's total output, including the intermediate products used and the value added during production. These output data, in both current and constant dollars, are produced by the Department of Commerce, Bureau of Economic Analysis and are available

\section{Conversion of SITC Price Index to SIC Price Index for} Transportation Equipment Industry

1997:Q1

\begin{tabular}{|ccccc}
\hline SITC Industry & Price Index & Weight & Price Index $*$ Weight \\
78 & 101.63 & 0.64 & 65.01 \\
79 & 100.53 & 0.36 & 36.22 \\
Sum of Weighted Indexes (SIC 37 Index) & & & & 101.24 \\
& & & & \\
\hline SITC Industry & 1998:Q1 & & Price Index * Weight \\
78 & Price Index & Weight & 65.19 \\
79 & 101.90 & 0.64 & 35.84 \\
\hline Sum of Weighted Indexes (SIC 37 Index) & 99.47 & & 0.36 & 101.02 \\
\hline
\end{tabular}


electronically at: বhttp://www.bea.doc. gov/bea/dn2.htm>. Current dollar gross output is roughly equival ent to an industry's sales or receipts. Our analysis uses the 1996 current dollar gross output data for each industry.

\section{Measuring the Effect of Changes in Exports on O utput}

The percentage change in the real exports of each industry to East Asia is given by Equation 1, as follows:

$$
\left(\frac{\sum_{j=1}^{10} X_{98, t}^{i, j}}{\sum_{j=1}^{10} X_{97, t}^{i, j}}-1\right) * 100
$$

where $X^{i, j}$ is the real exports of industry $i$ to country $j$ and the subscript $t$ refers to the quarter in 1998 and 1997. The results for each industry are given in Table 5.

Exports to East Asia as a share of the gross output of each industry in 1996 is given by Equation 2, as follows: where $X^{i, j}$ is the real exports of industry $i$
(2) $\left(\frac{\sum_{j=1}^{10} X_{96}^{i, j}}{Y_{96}^{i}}\right) * 100$

to country $j$, and $Y^{i}$ is the gross output of industry $\mathrm{i}$. The year 1996 is used to calculate the importance of the East Asian market for each industry because it is the latest year for which gross output data by industry are available. The results of this calculation are given in Table 6.

Combining the percentage change in exports with the share of exports in gross output indicates the effect of the change in exports on output, as shown by Equation 3, as follows:

(3)

$$
\left(\frac{\sum_{j=1}^{10} X_{98, t}^{i, j}}{\sum_{j=1}^{10} X_{97, t}^{i, j}}-1\right)\left(\frac{\sum_{j=1}^{10} X_{96}^{i, j}}{Y_{96}^{i}}\right) * 100
$$

The results of this calculation are given in Table 7. on output ( 0.1 percent) because only a small fraction of SIC 13 output is exported to East Asia ( 0.4 percent). Turning to the tobacco products industry (SIC 21), the limited effect on output ( 0.3 percent) results primarily from the small decline in these exports ( 4.9 percent).

The final two columns in Table 7 provide some perspective on the significance of these output effects. These two columns show the average and range of the contribution of exports to East Asia to the growth of gross output over the period 1990-96. In five industries- metallic ores and concentrates (SIC 10), bituminous coal and lignite (SIC 12), lumber and wood products (SIC 24), primary metal products (SIC 33) and tobacco products (SIC 21) - export declines, on average, reduced the growth rate of gross output. Even in these industries, however, the effect of the 1998 decline in exports to East Asia on gross output was greater than the average effect. Thus, for example, the decline in exports to East Asia in the metallic ores and concentrates industry had a 0.86 percentage point drag on the growth of gross output during 1998. On average, over the 1990-96 period, the decline in exports to East Asia in this industry lowered the growth rate of gross output by 0.29 percentage points.

In only nine of the 26 industries studied is the current negative export effect on growth of gross output within the range of experience throughout the 1990-96 period. Moreover, eight of the industries never experienced a decline in exports to East Asia during this period. N onelectrical machinery exports to East Asia, for example, contributed between 0.21 and 2.36 percentage points to the annual growth rate of gross output throughout the 1990-96 period. 


\section{Table 7}

\begin{tabular}{|c|c|c|c|c|c|c|c|c|}
\hline SIC & Industry & Year & Q1 & $\begin{array}{c}1998 \\
Q 2\end{array}$ & Q3 & Q4 & $\begin{array}{l}\text { Average } \\
1990-96\end{array}$ & $\begin{array}{l}\text { Range } \\
1990-96\end{array}$ \\
\hline 35 & Nonelectrical machinery & -1.77 & -1.03 & -1.75 & -2.13 & -2.14 & 0.86 & $0.21-2.36$ \\
\hline 39 & Miscellaneous manufactured goods & -1.29 & -1.38 & -1.54 & -1.53 & -0.66 & 0.41 & $-0.23-1.30$ \\
\hline 08-09 & Forestry and fishing & -1.27 & -1.17 & -1.92 & -1.13 & -0.90 & 0.22 & $-0.70-1.98$ \\
\hline 24 & Lumber and wood products, except furniture & -1.21 & -1.47 & -1.57 & -1.12 & -0.41 & -0.12 & $-0.36-0.19$ \\
\hline 31 & Leather and leather products & -1.06 & -1.98 & -0.20 & -1.05 & -0.98 & 0.41 & $-0.46-1.46$ \\
\hline $01-02$ & Agriculture and livestock products & -0.93 & -1.02 & -1.27 & -0.84 & -0.61 & 0.11 & $-0.85-1.72$ \\
\hline 36 & $\begin{array}{l}\text { Electrical and electronic machinery, } \\
\text { equipment, and supplies }\end{array}$ & -0.89 & -0.38 & -1.52 & -1.23 & -0.42 & 1.72 & $0.45-3.65$ \\
\hline 10 & Metallic ores and concentrates & -0.86 & -1.38 & -0.99 & 0.14 & -1.64 & -0.29 & $-1.89-1.52$ \\
\hline 28 & Chemicals and allied products & -0.78 & -0.90 & -0.84 & -0.94 & -0.42 & 0.19 & $-0.22-0.58$ \\
\hline 38 & $\begin{array}{l}\text { Scientific and professional instruments; } \\
\text { photographic and optical goods, etc }\end{array}$ & -0.76 & -0.23 & -0.61 & -0.94 & -1.23 & 0.51 & $-0.04-1.16$ \\
\hline 33 & Primary metal products & -0.57 & -0.34 & -0.71 & -0.69 & -0.53 & -0.01 & $-0.82-1.23$ \\
\hline 26 & Paper and allied products & -0.53 & -0.59 & -0.58 & -0.67 & -0.25 & 0.13 & $-0.17-0.45$ \\
\hline 32 & Stone, day, glass and concrete products & -0.46 & -0.33 & -0.40 & -0.44 & -0.66 & 0.13 & $0.04-0.32$ \\
\hline 23 & Apparel and related products & -0.39 & -0.43 & -0.40 & -0.43 & -0.30 & 0.18 & $0.03-0.32$ \\
\hline 30 & Rubber and miscellaneous plastics products & -0.30 & -0.22 & -0.34 & -0.40 & -0.26 & 0.11 & $0.04-0.19$ \\
\hline 12 & Bituminous coal and lignite & -0.36 & -0.05 & -0.39 & -0.50 & -0.53 & -0.16 & $-0.38-0.12$ \\
\hline 22 & Textile mill products & -0.27 & -0.10 & -0.30 & -0.38 & -0.31 & 0.03 & $-0.04-0.14$ \\
\hline 29 & Refined petroleum and coal products & -0.26 & -0.41 & -0.40 & -0.28 & 0.23 & 0.01 & $-0.39-0.29$ \\
\hline 21 & Tobacco products & -0.25 & -0.27 & 0.01 & -0.29 & -0.43 & -0.01 & $-0.85-1.01$ \\
\hline 34 & $\begin{array}{l}\text { Fabricated metal products except } \\
\text { machinery and transportation equipment }\end{array}$ & -0.22 & -0.17 & -0.39 & -0.42 & 0.11 & 0.12 & $0.01-0.24$ \\
\hline 14 & Nonmetallic minerals, except fuels & -0.19 & -0.18 & 0.13 & -0.42 & -0.28 & 0.12 & $0.04-0.22$ \\
\hline 25 & Furniture and fixtures & -0.14 & -0.14 & -0.19 & -0.12 & -0.11 & 0.06 & $0.01-0.11$ \\
\hline 13 & Crude oil and natural gas & -0.12 & -0.13 & 0.11 & -0.18 & -0.21 & 0.04 & $-0.13-0.26$ \\
\hline 20 & Food and kindred products & -0.07 & -0.07 & -0.01 & -0.17 & -0.04 & 0.11 & $-0.25-0.28$ \\
\hline 27 & Printing and publishing & -0.01 & -0.03 & 0.03 & -0.04 & 0.00 & 0.01 & $-0.03-0.04$ \\
\hline 37 & Transportation equipment & 0.14 & 0.49 & -0.77 & 0.05 & 0.92 & 0.31 & $-0.23-0.89$ \\
\hline
\end{tabular}

Sources: U.S. Department of Commerce, Bureau of Economic Analysis and Bureau of the Census; Department of Labor, Bureau of Labor Statistics.

Thus, the 1.77 percentage point export drag on growth in 1998 is particularly troublesome for this industry.

\section{CONCLUSION}

Throughout most of the 1990s the United States has enjoyed the benefits of rising exports, particularly those to the growing economies of East Asia. Over the past year, however, the East Asian economies have contracted and their currencies have fallen sharply against the dollar. As a result, demand for U.S. products has declined and U.S. exports to the region have fallen. In 1998 real U.S. exports to East Asia fell by 11.6 percent.

Examining the changes in exports by industry indicates the pervasi veness of the declines. Only the transportation equipment industry sent more goods to East Asia in 1998 than in 1997. This was a result of increases in aircraft exports, many of which were ordered prior to the economic problems in East Asia. 


\section{ANOTHER LOOK AT INDUSTRY OUTPUT EFFECTS}

Clearly our results are rough estimates of the sectoral effects of the Asian crisis on the U.S. economy. Prior studies, such as Noland et al. (1998) and Werling and McCarthy (1998), explore the relationship between different macroeconomic environments in Asia and their trade and production effects across U.S. industries. Because our approach uses actual trade changes, our results are not strictly comparable to prior studies. N onetheless, as a check on the reasonableness of our results, we compare our results with those generated by Noland et al. (1998).

Using a computable general equilibrium model with 17 regions, each with 14 sectors and five primary factors of production, Noland et al. explored the consequences of various macroeconomic scenarios. The Asian crisis was characterized as a combination of two types of shocks - real exchange rate depreciations and declines in GDP-in eight Asian

\begin{tabular}{lc}
$\begin{array}{l}\text { Medium Shock Scenario - } \\
\text { Output Effects (Percent) } \\
\text { Industry }\end{array}$ & $\begin{array}{c}\text { Change in Production } \\
\text { Machinery }\end{array}$ \\
Electronics & -2.63 \\
Forestry and fishery & -2.38 \\
Motor vehicles and parts & -1.39 \\
Other transportation equipment & -1.21 \\
Agriculture & -1.13 \\
Light manufacturers & -0.89 \\
Intermediate goods & -0.82 \\
Textile and apparel & -0.71 \\
Mining & -0.63 \\
Energy & -0.49 \\
Processed food & -0.01 \\
Services & 0.02 \\
Housing and construction & 0.39 \\
Total & 0.71 \\
Source: Noland et al. (1998), Table 3.1. & \\
\hline
\end{tabular}

countries. These shocks generate changes in trade flows and production.

The production changes associated with one scenario, termed the mediumshock scenario are listed in the table in this insert. Because the correspondence between the sectors used by N oland et al. and the two-digit SIC classification we use is rough and because their time horizon extends beyond 1998, it is difficult to make strong statements. ${ }^{1}$ It appears, however, that the cross-industry results are comparable. Similar to our results that the nonelectrical machinery industry has experienced the largest relative decline, Noland et al. identified the machinery sector as experiencing the largest relative decline. The electronics sector also was expected to experience relatively large declines, a result consistent with our finding for electrical and electronic machinery, equipment and supplies. In addition, $\mathrm{N}$ oland et al. found that both the agriculture sector and the forestry and fishery sector are likely to undergo relatively large production changesresults consistent with our findings for the industries encompassing agriculture and livestock (SIC 01-02) and forestry and fishing (SIC 08-09). The most obvious difference between our results and those of $\mathrm{N}$ oland et al. concerns potential changes in the transportation equipment industry. Noland et al. estimated relatively large changes; to date we estimate relatively small changes. ${ }^{2}$ Some of this difference can be attributed to the fact that $\mathrm{N}$ oland et al. also capture import effects that we do not.

\footnotetext{
${ }^{1}$ Noland et al. also do not include China and Hong Kong in their study. Excluding these from our sample does not change the comparability of the results.

${ }^{2}$ Our transportation equipment industry results are consistent with those of Werling and McCarthy (1998). They estimated belowaverage production declines for motor vehicles and parts. Meanwhile, for aerospace, which accounts for a relatively smaller share of the transportation equipment industry than motor vehicles, they did find above-average production declines.
} 
M oreover, more than half the industries studied experienced declines in exports to East Asia of more than 15 percent. Such declines are highly unusual. Between 1990-96 only nine of the 26 industries experienced a yearover-year decline in exports as large as the ones they experienced during 1998. Because the effects differ across industries and within the two-digit SIC industries, these export data also suggest that certain regions of the United States may be more affected by the export declines than other regions. ${ }^{12}$

Focusing solely on the export data overstates the rel evance of these declines to the industries in question and presents an inaccurate picture of the industries that have been hardest hit by the export effects of the Asian crisis. The effect of the decline in exports on the output of a particular industry depends on the extent to which that industry is dependent on the East Asian market to sell its output. Incorporating the export declines with the market share data indicates the extent to which each industry has been affected. For most of the industries studied, the decline in exports has lowered growth by 0.4 percentage points or less. For many industries, however, output declined by 1 percent or more. Generally speaking, our cross-industry results are consistent with the simulation results of $\mathrm{N}$ oland et al. (1998).

These results, however, need to be interpreted with care. They may be biased downward because they capture only the direct effects of a decline in exports to East Asia on industry output. They do not incorporate any secondary effects. Thus, for example, the stone, clay, glass and concrete products industry may be both directly affected by declining exports to East Asia and indirectly affected by reduced orders from other U.S. firms as a result of declining demand in East Asia. That is, as the amount of transportation equipment sold to East Asia declines, the transportation equipment industry's demand for window glass declines. On the other hand, increases in demand by U.S. and other foreign consumers and businesses may mitigate the effects of the decline in demand in East Asia.

Our focus on exports also ignores the potentially negative effects on some U.S. producers-decreased demand for their output stemming from increased imports. The steel industry is a specific example. ${ }^{13}$ Imports of steel rose by 24 percent during 1998. This surge in imports can be connected to the Asian crisis in that reduced steel demand throughout Asia has reduced the world price of steel and has lead producers, especially those from Russia, Japan and Brazil, to ship their excess steel to the United States. ${ }^{14}$

\section{REFERENCES}

Gazel, Ricardo C., and Russell L. Lamb. "Will the Tenth District Catch the Asian Flu? " Federal Reserve Bank of Kansas City Economic Review (second quarter 1998), pp. 9- 26.

Greenspan, Alan. "The Crisis in Emerging Market Economies," testimony before the U.S. Senate Committee on the Budget, September 23, 1998, <http:/ / www.bog.frb.fed. us/ boarddocs/ testimony/ 19980923.htm>.

Lucentini, Jack. "Commerce Could Soon Levy Steel Penalties," The Journal of Commerce (November 25, 1998).

Neely, Michelle Clark. "Paper Tigers? How the Asian Economies Lost Their Bite," Federal Reserve Bank of St. Louis Regional Economist (January 1999), pp. 5- 9.

Noland, Marcus, Li-Gang Liu, Sherman Robinson, and Zhi Wang. Global Economic Effects of the Asian Currency Devaluations. Institute for International Economics, 1998.

Roubini, Nouriel. "What Caused Asia's Economic and Currency Crisis and Its Global Contagion?" <http:/ / www.stem.nyu.edu/ nroubini/ asia/ AsiaHomepage.html>.

Valletta, Rob. "East Asia's Impact on Twelfth District Exports," Federal Reserve Bank of San Francisco Economic Letter (November 20, 1998).

Werling, Jeffrey F., and Margaret McCarthy. The Asian Crisis and U.S. Industry: An Industry Perspective. Manufacturers Alliance, 1998.

\footnotetext{
${ }^{12}$ See Valetta (1998) and Gazel and Lamb (1998) for an analysis of the regional effects of the decline in exports to East Asia.

${ }^{13}$ Though increased imports of steel might have adverse effects on U.S. producers of steel, the lower priced imports will benefit consumers and producers of goods requiring steel as an input.
${ }^{14} \mathrm{As}$ a result of the increase in U.S. steel imports, 12 U.S. steel companies in conjunction with the United Steelworkers of America, have filed dumping charges alleging that steel pro- ducers from Russia, Japan, and Brazil were selling steel in the United States below their pro- duction costs. See Lucentini (1998) for additional details.


MARCH/ APRIL 1999

FEDERAL RESERVE BANK OF ST. LOUIS 